\title{
Tre søsken med økende pustevansker som spedbarn
}

\author{
Utredning av sjeldne medfødte nevromuskulære sykdommer kan være \\ vanskelig. Selv om muskelbiopsi og nevrofysiologisk utredning gir viktig \\ informasjon, kan det være genetiske undersøkelser som gir fasiten - \\ noen ganger etter pasientens $\mathrm{d} \varnothing \mathrm{d}$.
}

Tidlig i 1990-årene fikk et ubeslektet foreldrepar en datter. Moren hadde et friskt barn fra et tidligere forhold. Svangerskap og fødsel var normale, fødselsvekt $3010 \mathrm{~g}$. Jenta hadde litt sitringer $i$ beina etter fødselen, men var for øvrig klinisk upåfallende.

Seks uker gammel ble hun akutt dårlig og innlagt $i$ den lokale barneavdelingen med rask og hvesende respirasjon. Hun hadde sitringer i beina, spontan ankelclonus bilateralt, dårlige gripereflekser i hender og føtter og varierende Moros refleks. Det var normalt EEG og normal cerebral ultralydundersøkelse, blodprøvene viste ingen klare avvik og metabolsk screening av urinen var normal.

Man mistenkte nevrologisk sykdom, men jenta kom seg noe og ble utskrevet, med avtale om kontrollinnleggelse etter to uker.

Litt sitringer hos nyfødte kan være et uspesifikt funn som man normalt ser an etter å ha utelukket hypoglykemi og hypokalsemi. Refleksforandringene som pasienten hadde ved seks ukers alder, kunne ha sentralnevrologisk årsak. Pustebesværet kunne skyldes viral luftveisinfeksjon.

Ved innleggelse to uker senere var tilstanden i hovedsak den samme, men pustemønsteret var mer påfallende og anstrengt. På grunn av mistanke om alvorlig nevrologisk sykdom ble jenta overflyttet til universitetsklinikk. Ved innleggelse der hadde hun takypné, interkostale inndragninger og paradokse abdominalbevegelser, men smilte og ga god blikkontakt. Hun hadde reduserte spontanbevegelser $i$ alle fire ekstremiteter og nedsatt muskeltonus. De dype refleksene var livlige, med ankelclonus, men likevel uten tydelig spastisitet. Hun lå mest i opistotonusstilling, og Moros refleks var vanskelig å utløse. Det ble ikke sett tungefascikulasjoner.

Røntgen thorax viste paradokse diafragmabevegelser. Spinalvæskeundersøkelse med elektroforese var normal (spinalprotein $0,26 \mathrm{~g} / \mathrm{log} 0,13 \mathrm{~g} / \mathrm{l}(0,10-0,30 \mathrm{~g} / \mathrm{l}))$, uten patologiske bånd, og hun hadde normal serumkreatinkinase (CK) på $104 \mathrm{U} / \mathrm{l}$ (35-210 U/L). Hurtigtester i urin for cytomegalovirus (CMV) var positive. Det ble ikke påvist cytomegalovirusantistoff $i$ serum eller spinalvæske. Cytomegalovirus ble heller ikke påvist ved dyrking, men moren hadde positiv serologisk prøve på viruset.

Muskelbiopsi viste intet patologisk. Ved nevrofysiologisk undersøkelse ved ni ukers alder var det funn som ved distal motorisk aksonal degenerasjon, men også redusert motorisk nerveledningshastighet som tegn på demyelinisering (tab 1).

Det kliniske bildet var uklart - med nevrologiske symptomer som kunne tyde på både sentral og perifer skade. Redusert motorisk nerveledningshastighet, men normal elektromyografi (EMG) og normal muskelbiopsi tydet ikke på muskelsykdom, men viste mer i retning en nerveaffeksjon, og normal serumkreatinkinase gjorde flere muskeldystrofier lite sannsynlige (1).

De bevarte livlige reflekser, ankelclonus og opistotonustendens tydet på at første orden motonevronbaner og kortikospinale baner kunne være affisert. Pasienter med hypoton cerebral parese kan ofte ha livlige dype reflekser (2). Paradoksale diafragmabevegelser og diafragmaparese tydet imidlertid på skade av n. phrenicus, og nevrofysiologisk undersøkelse viste også perifer nerveskade med demyelinisering. Muskulær hypotoni og reduserte spontanbevegelser kunne derfor ha både sentral og perifer årsak.

En demyeliniserende nevropati, GuillainBarrés sykdom, muligens utløst av cytomegalovirusinfeksjon, ble vurdert. Da ville man imidlertid vente spinalvæskeforandringer, og livlige reflekser passet heller ikke. Det ble antatt at de noe uklare cytomegalovirusfunn kunne skyldes overføring fra mor.

Tilstanden progredierte med økende perifere pareser, men jenta virket kvikk mentalt. Hun ble avhengig av respirator fra tre måneders alder. Gjennomlysing viste manglende diafragmakontraksjoner. Den bilaterale ankelclonus vedvarte, men hun bevarte noe bevegelighet $i$ armer og bein. Det var nedsatt kraft og umoden håndfunksjon.

Ved nye nevrofysiologiske undersøkelser

\section{Noralv Breivik}

noralv.breivik@mimer.no

Seksjon for habilitering

Barneavdelingen

Ålesund sjukehus

Torunn Fiskerstrand

Senter for medisinsk genetikk

og molekylærmedisin

Haukeland universitetssykehus

og

Institutt for klinisk medisin 2

Universitetet i Bergen

\section{Trond Sand}

Avdeling for nevrologi og klinisk nevrofysiologi St. Olavs hospital

og

Institutt for nevromedisin

Norges teknisk-naturvitenskapelige universitet

Christina Vogt

Avdeling for patologi og medisinsk genetikk

St. Olavs hospital

og

Institutt for laboratoriemedisin,

barne- og kvinnesykdommer

Norges teknisk-naturvitenskapelige universitet

Engelsk oversettelse på www.tidsskriftet.no 
Tabell 1 Klinisk nevrofysiologisk utredning inkludert måling av nerveledningshastighet hos pasient 1. Følgende funn er ikke er typiske for vanlig spinal muskelatrofi: lav motorisk nerveledningshastighet, aksonal sensorisk nevropati, normal elektromyografi i proksimale muskler og utslukket somatosensorisk fremkalt respons

Alder

\begin{tabular}{|c|c|c|c|c|}
\hline Undersøkelse & Stimulering & 9 uker & 8-10 måneder & 11,5 måneder \\
\hline \multirow[t]{2}{*}{ Motorisk nerveledning } & Arm & & $\begin{array}{l}\text { Normal, men avtakende amplitude. } \\
\text { Lav nerveledningshastighet }(20-27 \mathrm{~m} / \mathrm{s})\end{array}$ & $\begin{array}{l}\text { Lav amplitude Litt lav nerve- } \\
\text { ledningshastighet }(25 \mathrm{~m} / \mathrm{s})\end{array}$ \\
\hline & Bein & $\begin{array}{l}\text { Lav amplitude og lav } \\
\text { nerveledningshastighet } \\
(8 \mathrm{~m} / \mathrm{s})\end{array}$ & Ikke respons & Ikke respons \\
\hline \multirow[t]{2}{*}{ Sensorisk nerveledning } & Arm & $\begin{array}{l}\text { Normal nervelednings- } \\
\text { hastighet }(19 \mathrm{~m} / \mathrm{s})\end{array}$ & $\begin{array}{l}\text { Lav amplitude Normal nervelednings- } \\
\text { hastighet ( } 30 \mathrm{~m} / \mathrm{s} \text { ) }\end{array}$ & Ikke respons \\
\hline & Bein & $\begin{array}{l}\text { Normal nervelednings- } \\
\text { hastighet }(19 \mathrm{~m} / \mathrm{s})\end{array}$ & Ikke respons & Ikke respons \\
\hline \multirow[t]{2}{*}{ Elektromyografi } & Distale muskler & Normalt & Nevrogent mønster & Nevrogent mønster \\
\hline & $\begin{array}{l}\text { Proksimale } \\
\text { muskler }\end{array}$ & Normalt? & & Normalt \\
\hline $\begin{array}{l}\text { Somatosensorisk } \\
\text { fremkalt respons }\end{array}$ & $\begin{array}{l}\text { N. medianus } \\
\text { ved håndleddet }\end{array}$ & & & $\begin{array}{l}\text { Ikke respons } \\
\text { (perifer A-betanevropatil }\end{array}$ \\
\hline $\begin{array}{l}\text { Akustisk hjernestam- } \\
\text { merespons }\end{array}$ & Klikkelyd i ørene & & & Normalt \\
\hline
\end{tabular}

da jenta var åtte og $11 \frac{1}{2}$ måneder viste nevrografi økende aksonal degenerasjon av motoriske og sensoriske nerver. Elektromyografi viste denervasjonsaktivitet med uttalt denervasjon av distal muskulatur og mer uspesifikke svar i proksimal muskulatur. Somatosensorisk fremkalt respons viste

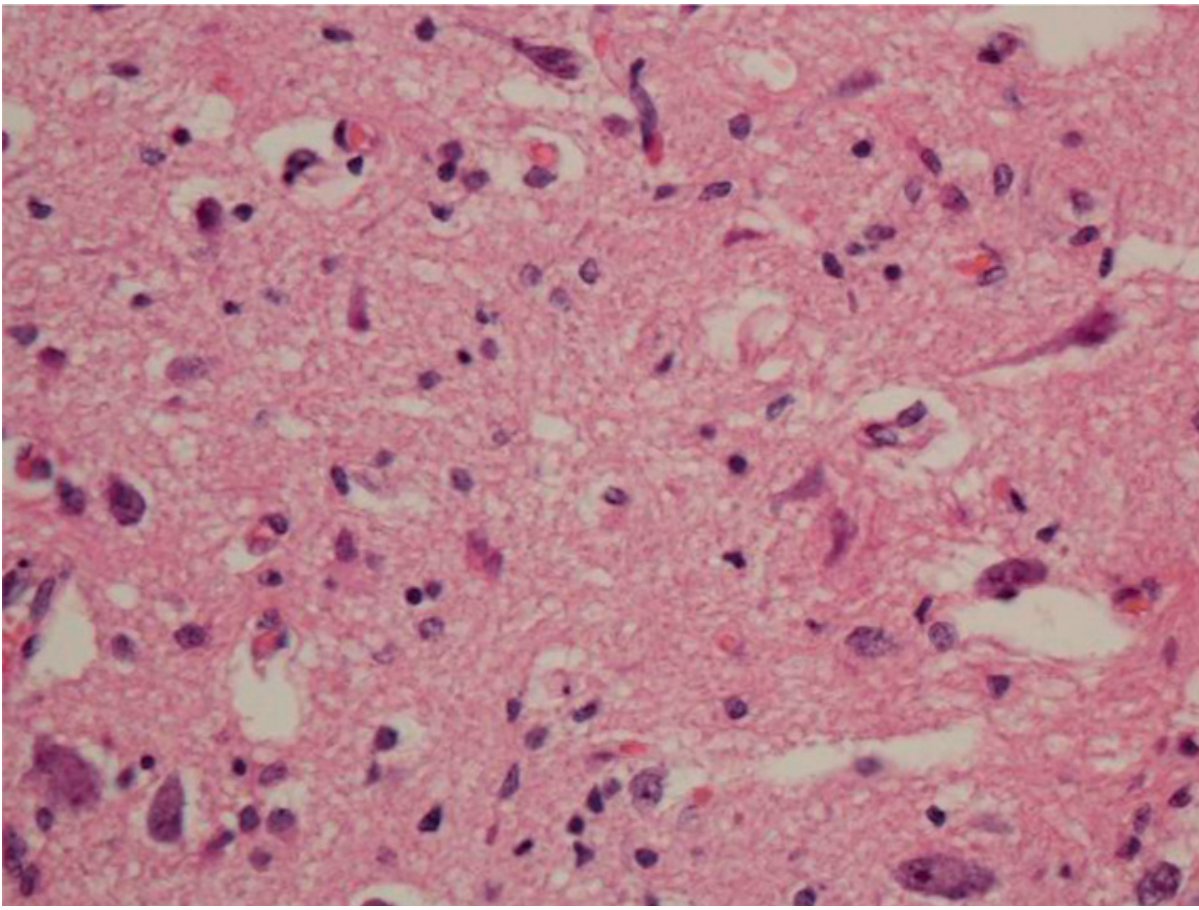

Figur 1 Forhorn, mulig nervecelletap (subtilt) og lett reaktiv gliose. Foto David Scheie ingen perifere eller sentrale responser, tolket som affeksjon av perifere myeliniserte sensoriske nerver, mens den akustiske hjernestammeresponsen var normal (tab 1). Ny biopsi fra m. gastrocnemius ved 11 måneders alder viste storgruppet denervasjonsatrofi, forenlig med spinal muskelatrofi.
Undersøkelsene viste nå klart at også nedre motonevron hadde aksonal skade med denervasjon av muskulaturen. Motoriske nerver var mer affisert, og elektromyografi viste nevrogent mønster.

Det så ut til å dreie seg om en nevromuskulær sykdom, med mer og mer preg av progredierende muskelatrofi, mens affeksjon av sensoriske nerver passet dårlig med isolert nevromuskulær lidelse. Det ble aldri observert fascikulasjoner, som kan være funn ved spinal muskelatrofi.

Jenta døde 14 måneder gammel.

Ved obduksjon var det normale funn $i$ hjerne, lillehjerne og hjernestamme. Diafragma var løvtynn, og i snitt fra diafragma og muskulatur i over- og underekstremiteter fantes en uttalt storgruppeatrofi. Primært ble det ikke beskrevet svinn av nerveceller i medulla spinalis.

$21 / 2$ år senere beskrev en annen nevropatolog nervecellesvinn $i$ de motoriske forhorn $i$ torakalmedulla, med fibersvinn $i$ fremre røtter. Det var ikke fibersvinn i sensoriske røtter. Snitt fra perifere nerver viste fibrose og bare enkelte myeliniserte fibre. Det var ingen holdepunkter for GuillainBarrés syndrom.

De patologiske funn sammenholdt med de nevrofysiologiske var forenlig med progredierende spinal muskelatrofi. Den alvorligste infantile formen kalles Werdnig-Hoffmanns 
sykdom, en recessivt arvelig tilstand. Sensorisk affeksjon og den uttalte affeksjonen av diafragma passet imidlertid ikke med vanlig Werdnig-Hoffmanns spinal muskelatrofi, og pasienten fikk derfor diagnosen «variant av Werdnig-Hoffmanns sykdom med storgruppert denervasjonsatrofi i diafragma». Det kunne imidlertid også tenkes at de nevrofysiologiske funn var resultat av en hereditær motorisk-sensorisk nevropati (1).

Foreldrene ble informert om at det kunne være en gjentakelsesrisiko på $25 \%$.

Tre år senere fikk paret en sønn, som veide $3650 \mathrm{~g}$. Det var normale diafragmabevegelser ved gjennomlysing. Fem uker gammel ble han innlagt i lokalsykehus med økende pustevansker og ble så overflyttet til universitetsklinikk. Røntgen thorax viste høystand av høyre diafragma, skråstilt venstre diafragmakuppel og etter hvert paradoksal respirasjonsbevegelse.

Man antok at gutten hadde samme tilstand som søsteren. Foreldrene ønsket ikke respiratorbehandling. Han døde ni uker gammel og ble ikke obdusert.

Etter ytterligere ett år fikk foreldrene en sønn til. Gutten veide $3500 \mathrm{~g}$ og hadde normal apgarskår. Foreldrene reagerte også nå på litt sitringer. Det var normale diafragmabevegelser ved gjennomlysning. Fire uker gammel fikk han respirasjonsvansker. Gjennomlysing viste høystand og invers bevegelse av fremre del av høyre diafragmakuppel. Det ble ikke gitt respiratorbehandling, og gutten døde da han var $71 / 2$ uke.

Ved obduksjon ble det funnet tynn diafragma, på kun 1-2 mm. Det var svinn av forhornceller i medulla spinalis (fig 1), med usedvanlig små fremre røtter (fig 2). Det var også mulig fibersvinn i kortikospinale baner gjennom hele hjernestammen og i tractus corticospinalis lateralt $i$ medulla. I diafragma fantes spredte grupper av atrofiske fibre og spredte hypertrofiske fibre (fig 3). I skjelettmuskulatur fantes områder med muskelatrofi (fig 4). Det ble fortsatt konkludert med en variant av Werdnig-Hoffmanns sykdom.

I 2001 ble det kjent at spinal muskelatrofi med diafragmaparese kunne skyldes mutasjoner i immunglobulin $\mu$-bindende protein 2-genet (IGHMBP2-genet) på kromosom 11q13.2q13.4 (3). Med tillatelse fra foreldrene ble prøve fra jenta noen år senere undersøkt ved Institut für Humangenetik, Charité Centrum für Frauen-, Kinder- und Jugendmedizin mit Perinatalzentrum und Humangenetik, Berlin.

De fant at jenta var sammensatt heterozygot for to mutasjoner i IGHMBP2-genet. På det ene kromosomet ble det funnet en missensemutasjon - c. 1263C >A (p.Ser421Arg) -

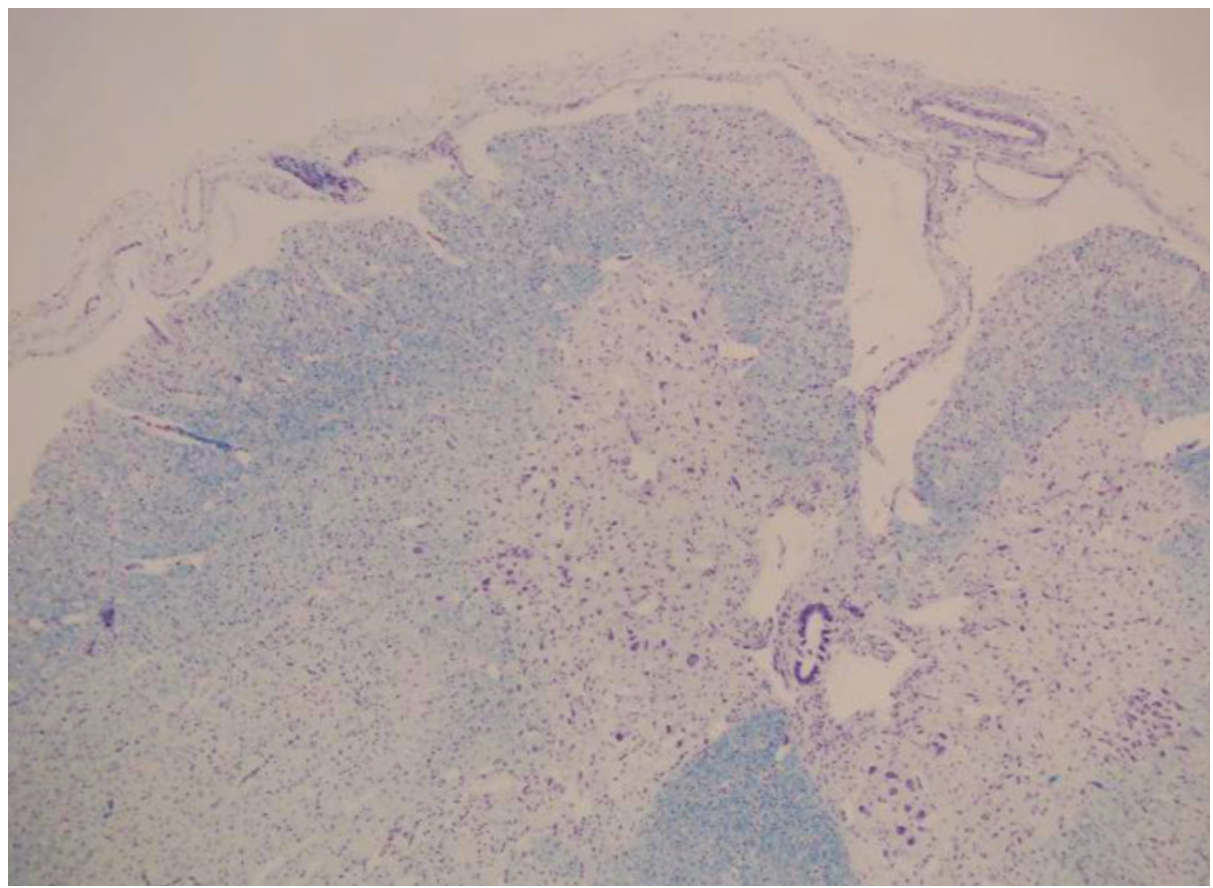

Figur 2 Medulla spinalis, tynn fremre rot loppe til venstre). Foto David Scheie

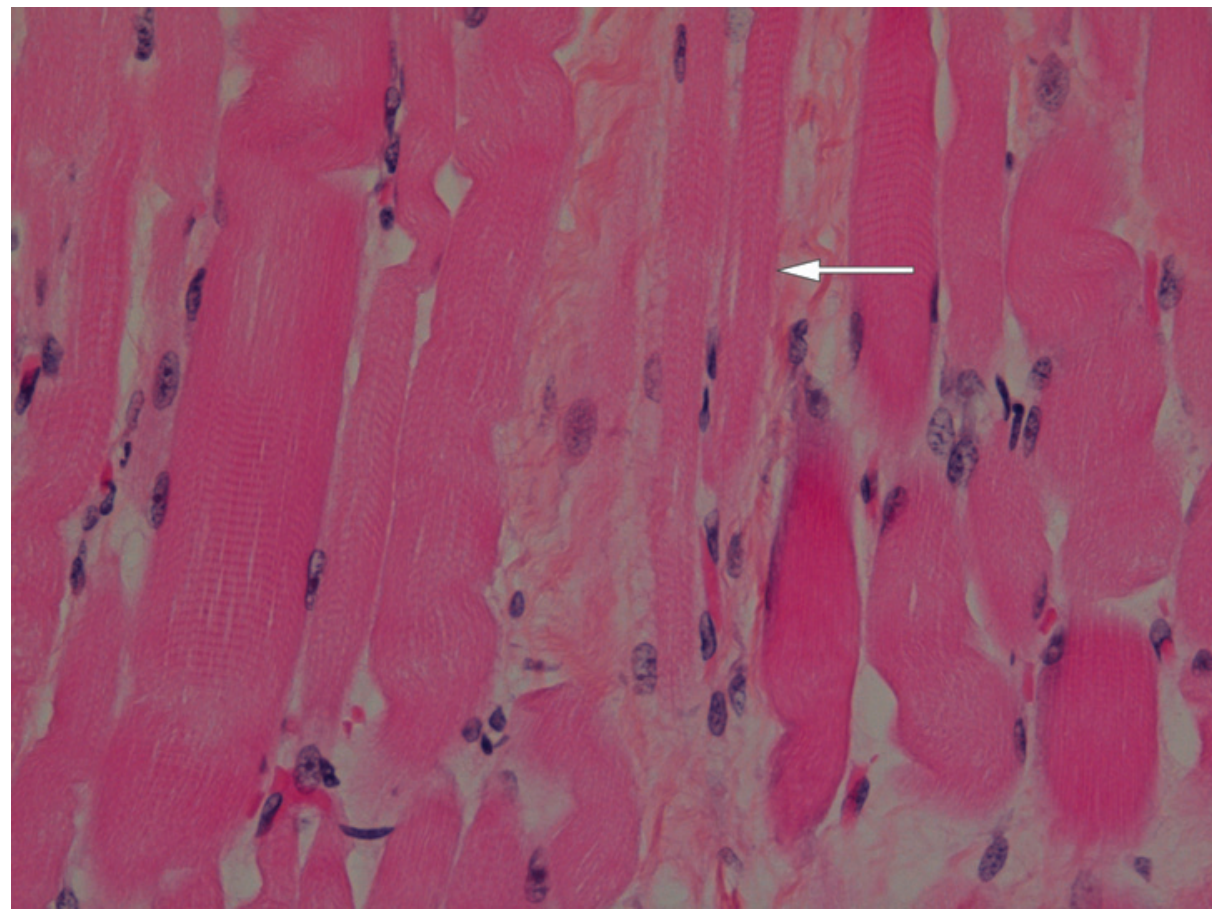

Figur 3 Snitt fra diafragma viser atrofiske muskelfibre (pill. Foto Christina Vogt

i ekson 9 som ikke er rapportert tidligere, på det andre en kjent missensemutasjon c. 1478C>T (p.Thr493Lys) - i ekson 10. Begge mutasjonene var lokalisert til et funksjonelt viktig område i IGHMBP2-genet.

Det var tidligere vist at de tre søsknene hadde arvet de samme genstrengene fra mor og far i området for IGHMBP2-genet. Brød- rene måtte ha samme mutasjoner og samme diagnose som søsteren.

\section{Diskusjon}

Spinale muskelatrofier er autosomalt recessive sykdommer som tidligere ble klassifisert etter kliniske funn støttet av nevrofysiologiske undersøkelser og muskelbiopsi. Spinal muskelatrofi type 1 (SMA1), 


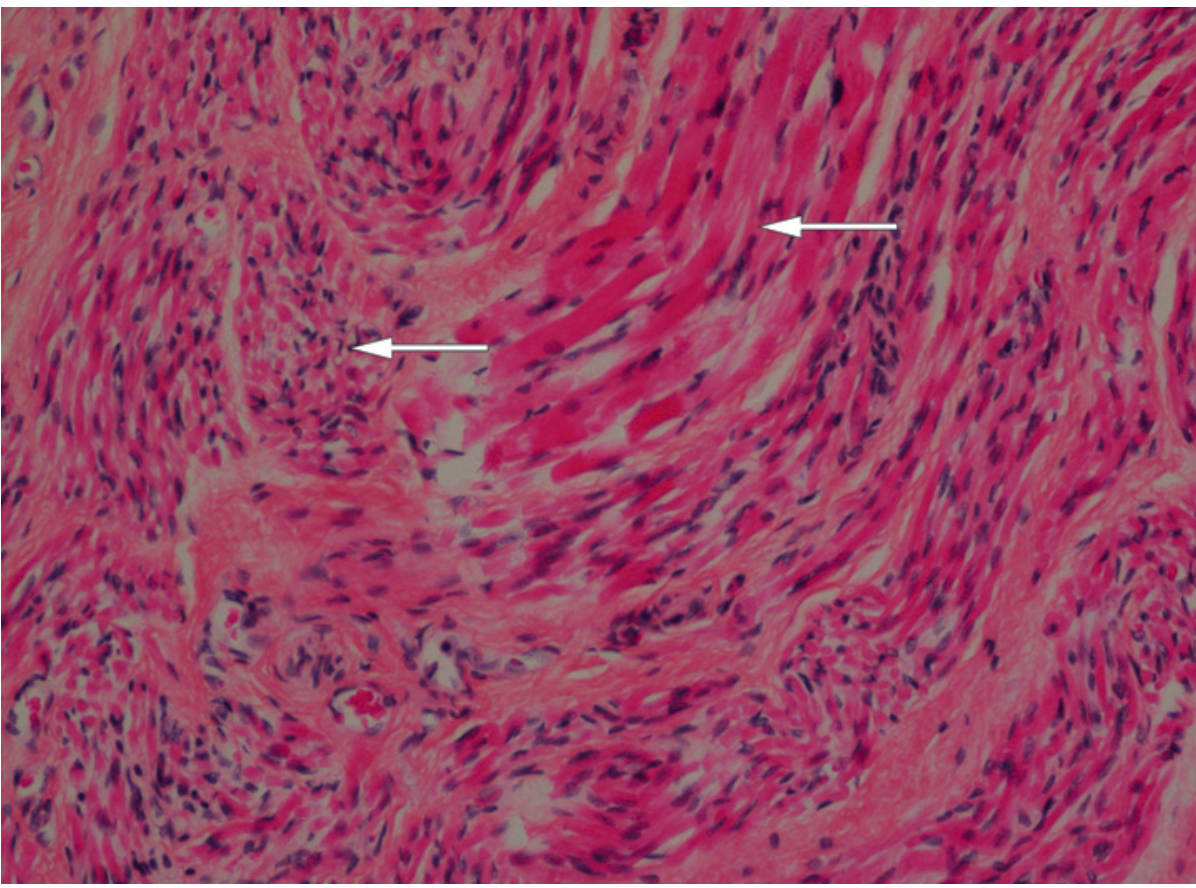

Figur 4 Snitt fra underarmsmuskulatur viser gruppert muskelatrofi med atrofiske fibre (venstre pill) som omslutter en bunt med tilnærmet normale fibre (pil). Foto Christina Vogt

eller Werdnig-Hoffmanns sykdom, har en varierende insidens, i Sverige ca. 1/28 000 levendefødte (4).

Den vanligste årsaken til spinal muskelatrofi er mutasjoner i genet SMN1, men $5 \%$ av pasientene har ikke mutasjoner i dette genet (5). Blant disse finnes en klinisk gruppe hvor respirasjonen svikter tidlig. Dette blir kalt spinal muskelatrofi med respirasjonsvansker (spinal muscular atrophy with respiratory distress, SMARD). Noen pasienter med spinal muskelatrofi med respirasjonsvansker er klinisk normale ved fødselen, men får tidlig respirasjonssvikt på grunn av sviktende diafragmafunksjon. Denne gruppen går nå under betegnelsen SMARD type 1 (3).

Svekkelsen av diafragmamuskelen gir eversjon av diafragma og paradoks bevegelse. Disse pasientene får degenerasjon av perifere nerver, også sensoriske og autonome, og har oftest mest affeksjon av distal muskulatur. Dype reflekser kan være bevart $(6,7)$. Det er vist at omtrent en tredel av disse har mutasjoner i det såkalte immunglobulin $\mu$-bindende protein 2-genet (IGHMBP2) (3, 6-10), og kombinasjonen av respirasjonssvikt $i$ perioden 6 uker- 6 måneders alder og diafragmaeventrasjon eller prematur fødsel predikerer mutasjon med $98 \%$ sensitivitet og $92 \%$ spesifisitet (8). De som ikke har mutasjon, har annen alder ved debut, eventuelt medfødte vansker eller multiple kontrakturer, indikasjon på tidlig intrauterin sykdomsutvikling.

En nylig påvist differensialdiagnose til SMARD1 er EMARDD (early onset myo- pathy, areflexia, respiratory distress and dysphagia), som skyldes mutasjoner i et annet gen kalt MEGF10 (11). Disse pasientene har også diafragmasvakhet, men myopati er et dominerende trekk. Det vil sannsynligvis komme rapporter om nye genetiske differensialdiagnoser innenfor tilstanden SMARD, på bakgrunn av videre kartlegging av pasientgruppen ved hjelp av ny sekvenseringsteknologi.

Det er beskrevet ca. 60 ulike mutasjoner i IGHMBP2-genet, og antallet øker. Det er mulig dette har betydning for fenotypisk variasjon. Hos vår pasient ble det også funnet en ny mutasjon. Pasientene er homozygote eller kompleks heterozygote for mutasjonene, som våre. Pasienter med mutasjon bare i det ene allelet er beskrevet, men den kliniske betydning er da ikke klarlagt (7). Noen få pasienter har symptomdebut allerede ved to ukers alder (7), noen få debuterer betydelig senere (8). Det finnes også sjeldne juvenile former med mindre alvorlige kliniske tegn (12). Selv hos søsken med de samme mutasjoner er det beskrevet betydelig klinisk variasjon $(8,10,13)$, og modifiserende gener påvirker sykdomsforløpet (14).

Våre pasienter ble vurdert som klinisk normale ved fødselen. I ettertid er det naturlig å tenke at sitringene sannsynlig har vært det første sykdomstegn. Alle tre fikk respirasjonsvansker ved 4-6 ukers alder. Det ble påvist paradoks diafragmabevegelse, og alle kunne klinisk klassifiseres som pasienter med SMARD1.

Genetiske årsaker til SMARD1 ble ikke kjent før flere år etter at vår yngste pasient var død. Sykehistorien til jenta viser hvor vanskelig det er å finne frem til en sikker diagnose uten genetisk diagnostikk. Forskjellige spesialister gjorde forskjellige funn og kom med dels avvikende vurderinger og konklusjoner. Selv etter obduksjon av to av pasientene, med vurderinger fra erfarne nevropatologer, var det vanskelig å komme frem til endelig diagnose.

De nevropatologiske funn hos disse pasientene varierer. Hos alle finner man muskelatrofi, og mange beskriver forandringer i perifere nerver. Selv om tilstanden oppfattes som spinal muskelatrofi, har ikke alle funnet de forandringer i medullas forhornceller som man ville vente (7). Hos våre pasienter som ble undersøkt, beskrives svinn av nevroner. Både nevropatologiske funn og nevrofysiologiske resultater tyder på perifer aksonal affeksjon og/eller progredierende affeksjon av både motoriske og sensoriske nevroner, der motoriske nevroner blir tidligst og mest affisert.

Nevrofysiologien har fortsatt en plass $i$ diagnostikken av barn med atypisk nevromuskulær sykdom der genetiske analyser ikke har gitt en diagnose $(15,16)$. Ved spesifikk klinisk mistanke bør imidlertid genetiske undersøkelser være det primære (17).

For foreldrene var det en ufattelig tragedie å miste alle sine felles barn. Man støttet foreldrene i deres behandlingsvalg når det gjaldt sønnene. Hadde man kjent diagnosen og prognosen for den første pasienten, ville avgjørelsen om å starte mekanisk ventilering vært vanskeligere. Vurderinger og praksis varierer (18), siden også disse pasientene kan leve i mange år med respiratorbehandling $(19,20)$. Det finnes ingen etablert behandling, men den økende forståelsen av SMA-gruppens genetiske bakgrunn har ført til utprøvning av potensielle medikamenter (21).

Bærerfrekvens og hyppighet av nyoppståtte mutasjoner i vår befolkning er ukjent. $\mathrm{Vi}$ antar at våre pasienter er de første som er diagnostisert med SMARD type 1 i Norge.

Sykehistorien viser betydningen av å ta vare på materiale (miltprøve, hudbiopsi eller EDTA-blodprøve (etylendiamintetraacetat)) for senere DNA-undersøkelser. Her ble årsaken funnet mer enn ti år etter at første pasient døde.

Foreldrene er gjort kjent med resultatet. Bekreftelsen av en svært alvorlig prognose gir i ettertid støtte for de valg de sammen med helsepersonell gjorde.

Barnas foreldre har gitt samtykke til at artikkelen blir publisert.

Vi takker overlege David Scheie ved Avdeling for patologi, Oslo universitetssykehus, Rikshospitalet, for to av fotografiene. 


\section{Noralv Breivik (f. 1943)}

er spesialist i barnesykdommer med spesialkompetanse i barnenevrologi og habilitering. Han er pensjonert seksjonsoverlege fra Seksjon for habilitering.

Forfatter har fylt ut ICMJE-skjemaet og oppgir ingen interessekonflikter.

\section{Torunn Fiskerstrand (f. 1965)}

er spesialist i medisinsk genetikk med spesialkompetanse innen laboratoriediagnostikk og søk etter ukjente sykdomsgener. Hun er overlege og postdoktorstipendiat.

Forfatter har fylt ut ICMJE-skjemaet og oppgir ingen interessekonflikter.

\section{Trond Sand (f. 1952)}

er spesialist i klinisk nevrofysiologi og nevrologi. Han er seksjonsoverlege og professor. Forfatter har fylt ut ICMJE-skjemaet og oppgir ingen interessekonflikter.

\section{Christina Vogt (f. 1945)}

er spesialist i patologi med spesialkompetanse i perinatal-og barnepatologi. Hun er overlege og professor

Forfatter har fylt ut ICMJE-skjemaet og oppgir ingen interessekonflikter.

\section{Litteratur}

1. Volpe JJ. Neurology of the newborn. 2. utg. Philadelphia, PA: W.B. Saunders Company, 1987 $539-41$.
2. Dubowitz V. The floppy infant. 2. utg. London: Spastics International Medical Publication: Heinemann Medical, 1980:99.

3. Grohmann K, Schuelke M, Diers A et al. Mutations in the gene encoding immunoglobulin $\mu$-binding protein 2 cause spinal muscular atrophy with respiratory distress type 1. Nat Genet 2001; 29: $75-7$

4. Arkblad E, Tulinius M, Kroksmark A-K et al. A population-based study of genotypic and phenotypic variability in children with spinal muscular atrophy. Acta Paediatr 2009: 98: 865-72.

5. Novelli G, Capon F, Tamisari L et al. Neonatal spinal muscular atrophy with diaphragmatic paralysis is unlinked to 5q11.2-q13. J Med Genet 1995; 32: $216-9$.

6. Giannini A, Pinto AM, Rossetti $G$ et al. Respiratory failure in infants due to spinal muscular atrophy with respiratory distress type 1. Intensive Care Med 2006; 32: $1851-5$

7. Pitt $M$, Houlden $H$, Jacobs J et al. Severe infantile neuropathy with diaphragmatic weakness and its relationship to SMARD1. Brain 2003; 126 2682-92

8. Guenther UP, Varon R, Schlicke M et al. Clinical and mutational profile in spinal muscular atrophy with respiratory distress (SMARD): defining novel phenotypes through hierarchical cluster analysis. Hum Mutat 2007; 28: 808-15.

9 Grohmann K Varon R Stolz P et al. Infantile spinal muscular atrophy with respiratory distress type 1 (SMARD1). Ann Neurol 2003; 54: 719-24.

10. Kaindl AM, Guenther U-P, Rudnik-Schöneborn S et al. Spinal muscular atrophy with respiratory distress type 1 (SMARD1). J Child Neurol 2008: 23: $199-204$.

11. Logan CV, Lucke B, Pottinger $C$ et al. Mutations in MEGF10, a regulator of satellite cell myogenesis, cause early onset myopathy, areflexia, respiratory distress and dysphagia (EMARDD). Nat Genet 2011; 43: 1189-92.

12. Guenther UP, Schuelke M, Bertini E et al. Genomic rearrangements at the IGHMBP2 gene locus in two patients with SMARD1. Hum Genet 2004; 115: $319-26$.
13. Joseph S, Robb SA, Mohammed S et al. Interfamilial phenotypic heterogeneity in SMARD1. Neuromuscul Disord 2009. 19: 193-5.

14. Maystadt I, Zarhrate M, Landrieu P et al. Allelic heterogeneity of SMARD1 at the IGHMBP2 locus. Hum Mutat 2004; 23: 525-6.

15. Jones HR Jr. EMG evaluation of the floppy infant: differential diagnosis and technical aspects. Muscle Nerve 1990; 13: 338-47.

16. Cetin E, Cuisset JM, Tiffreau V et al. The value of electromyography in the aetiological diagnosis of hypotonia in infants and toddlers. Ann Phys Rehabil Med 2009; 52: 546-55.

17. Darras BT, Jones HR Jr. Diagnosis of pediatric neuromuscular disorders in the era of DNA analysis. Pediatr Neurol 2000; 23: 289-300.

18. Bush A. Spinal muscular atrophy with respiratory disease (SMARD): an ethical dilemma. Intensive Care Med 2006; 32: 1691-3

19. Rudnik-Schöneborn S, Stolz P, Varon R et al. Long-term observations of patients with infantile spinal muscular atrophy with respiratory distress type 1 (SMARD1). Neuropediatrics 2004; 35 $174-82$

20. Eckart M, Guenther UP, Idkowiak J et al. The natural course of infantile spinal muscular atrophy with respiratory distress type 1 (SMARD1). Pediatrics 2012; 129: e148-56.

21. Lunn MR, Wang $\mathrm{CH}$. Spinal muscular atrophy. Lancet 2008; 371: 2120-33.

Mottatt 6.8. 2012, første revisjon innsendt 10.1. 2013, godkjent 21.5. 2013. Medisinsk redaktør Kristin Viste. 